\title{
Odpor učitelů vůči změnám ve škole a ve školství
}

\author{
JiŘí MAREš
}

Pokud má možnost výběru, většina škol preferuje stabilitu před změnou. Proč?

Fred C. Lunenburg (2010)

\begin{abstract}
Abstrakt: Přehledová studie konstatuje, že zavádèni zmèn ve školství (od velkých koncepčnich reforem až po zmèny na úrovni konkrétni školy) se u části učitelì zpravidla setkávás svýhradami. Studie akcentuje psychologický pohled na odpor učitelu ke zmènám ve škole a ve školství. Je strukturována do pèti částí. Prvni cáast príbližuje rưzná chápáni pojmu změna ve školském kontextu. Druhá část studie charakterizuje obtiže, které jsou spojeny s definováním a interpretováním pojmu odpor učiteli vi̊či změnè. Upozorňuje, že kritické postoje učitelù vůči změnám nelze ztotožňovat súplnou negací změny. Nejen, že postoje a jednání učitelü bývají spišse ambivalentni a mèni se včase, ale mivaji i pozitivni funkci: udržuji stabilitu systému, bránípovrchnim, nedomyšleným zmènám a nekriticky prijímaným inovacim. Pokud jim vedeni naslouchá, mohou iniciovat debatu, která půjde do bloubky a může prinést podněty na vylepšeni piovodni podoby změny. Seriózně koncipovaný odpor vưči zmèně může změnit zmènu k lepšimu. Trètí cást studie shrnuje současné poznatky o faktorech, které zmèny ve školstvi podporuji a o faktorech, které zmènám brání. Cturtá část se soustreduju na metody, jimiž lze miru odporu učitelì ke zmènè diagnostikovat. Prezentuje základni uidaje o použivaných dotaznicich, o kvalitativnich prìstupech a o smišených výzkumech. Závěrečná ćást se zamýšli nad tím, čím se odpor učitelü vůči změnám ve škole a ve školstvi pravdèpodobně liši od odporu pracovnikư v jiných institucich a v jiných resortech. Přpominá, že existuji rozdily v podobè a fungováni školství i mezi zemémi sobdobnými sociokulturnimi podminkami.
\end{abstract}

Kličová slova: školství, škola, změna, odpor ke zmènè, učitelé, diagnostika.

\section{ÚvoD}

Změny, které se odehrávají ve školství, byly, jsou a zrejmě budou předmětem diskusí mezi učiteli, kteří je mají uskutečňovat, ale také diskusí mezi laiky i mezi samotnými odborníky. Německý autor Terhart trefně konstatoval: ví se, že každá edukační realita zaostává za vývojem, nesplňuje současné požadavky na výchovu a vzdělávání. $V$ tomto směru každá edukační realita může být zlepšena a zpravidla 
by měla být zlepšována, tj. reformována. Protože reformování bývá považováno vždy za správný počin, je pak skeptický postoj učitelů $\mathrm{k}$ reformě nebo dokonce jejich odpor $\mathrm{k}$ reformě považován za podezřelou záležitost. Je však obtížné zkoumat „odpor učitelů vůči školské reformě“, protože toto téma je plné zkreslených a chybných pohledů, vzájemného obviňování a velké dávky moralizování. Je to ožehavý problém, nebot sám pojem „reforma“ je jedním ze základních pojmů pro pedagogiku i školství, pojmů důležitých a vlastně věčných (Terhart, 2013). Hargreaves před časem prohlásil, že edukační změna je de facto trvalým aspektem učitelské profese (Hargreaves, 1998).

Podíváme-li se do zahraničí, ukazuje se, že empirické výzkumy odporu učitelů vůči změnám ve školství nesouvisí s tendencí, kterou v posledních desítkách let pozorujeme ve vyspělých zemích. Pod označením new public management jsme svědky přenášení klíčových pojmů a metodologických postupů z privátního ekonomického sektoru do institucí, které spadají do veřejného sektoru (tedy i do škol). Terhart (2013) konstatuje, že odpor učitelů vůči změnám a inovacím ve škole a výuce se nevynořil jako závažný problém až v poslední době, není „objevem“ tohoto manažerského trendu. Odpor učitelů vůči změnám je stálý a opakující se jev, s nímž se v minulosti musely vypořádat všechny školské reformy.
Jaká je situace v České republice? Přes pokroky českého pedagogického výzkumu máme zatím $\mathrm{k}$ dispozici výsledky dílčích sond, nikoli celkový obraz o aktuálním stavu a vývojových trendech učitelských postojů vưči změnám ve školství, učitelské kritiky navrhovaných změn; chybí nám znalost argumentů, proč část učitelů se změnami nesouhlasí. Od roku 2002 se v ČR př́liliš nezlepšila situace, kterou charakterizoval J. Průcha takto: jsou málo objasněny postoje českých učitelů ke změnám, inovacím a reformám českého školství (Průcha, 2002). Zejména - ale to už dodáváme my - není u nás důkladně empiricky ${ }^{1}$ prozkoumána proměnná, kterou v zahraničí označují jako odporování učitelů změnám ve školství.

O jaké změny se v českém školství jedná? Mưžeme je ilustrovat príklady z materiálu, který nese označení Audit vzdělávacího systému $v \check{C} R(2017)$ a vydala ho obecně prospěšná společnost EDUin. Uvádí se v něm, že systémové reformy regionálního vzdělávání probíhají bez podpory samotných učitelů, bez analýz ex ante a ex post; pokud jsou někde provedeny, jejich závěry nebývají respektovány (Audit, s. 11).

Autoři materiálu dokládají své tvrzení dvěma př́klady: 1 . Přechod $\mathrm{z}$ pevně daných osnov na Rámcové vzdělávací programy $\mathrm{v}$ nultých letech proběhl $\mathrm{v}$ mnoha př́ípadech pouze formálně, bez důvěry učitelů a bez jejich aktivní účasti (Zelená,

${ }^{1}$ Jedním z důsledků neexistence rozsáhlejších empirických výzkumů je situace, kdy v České republice máme k dispozici spíše výsledky př́padových studií (např. Dvořák et al., 2010), nebo výsledky dílčich empirických sond $\mathrm{v}$ podobě bakalárských či diplomových prací studentů kombinované formy studia, tj. učitelů a ředitelů působících v praxi. V této přehledové studii (i při vědomí limitů takovýchto kvalifikačních prací) je zmiňujeme, nebot přinášejí drobné empirické vhledy do problémů, s nimiž se běžné české školy potýkají. 
2011). Závažné je, že MŠMT nedisponovalo vlastními průzkumy o postojích učitelů $\mathrm{k}$ této reformě. 2. Při zavádění inkluze, tj. při přechodu na poskytování podpůrných opatření žákům se speciálními potřebami $\mathrm{v}$ hlavním vzdělávacím proudu základních škol, je od počátku zřejmé, že postoje učitelů jsou negativní a hrozí, že tento fakt inkluzi na základních školách výrazně zkomplikuje (Straková, Spilková, Friedlaenderová et al., 2014).

Nejde však jenom o konstatování faktů, ale - jak připomíná Štech - o jejich korektní interpretování. Před unáhlenou interpretací edukačních jevů i chování aktérů nás může podle autora chránit vývojově-historický pohled. Proč se některé poznatky stávají významnými až v této době? Určující jsou podle něj trri faktory: 1 . nové potřeby společnosti, které "vytvářeji“" nové předměty zkoumání; 2. vývoj vědních oborů, který prrispívá $\mathrm{k}$ elaboraci nových metod zkoumání, preferovaných výzkumných postupů; ty si „ríkaji“ o prozkoumání určitého tématu; 3 . stupeň připravenosti oboru získané poznatky teoreticky uchopit a převést je do konzistentního, důkazy podloženého a věrohodného sdělení, které jde nad běžná mínění lidí (Štech, 2014). Lze to doložit analýzou, kterou uskutečnili spolupracovníci časopisu Journal of Educational Change (Garcia-Huidobro et al., 2017). Časopisu, který již od svého založení je prostorem pro diskusi o změnách ve školství různých zemích i změnách školy obecně. Autoři zvolili období 2000-2014 a za každý rok vybrali 2-7 článků (bylo jich celkem 52 z celkového počtu 467 článků). Šlo o články, které se nejvýrazně- ji podílely na celkovém počtu citací všech článků vyšlých $\mathrm{v}$ daném roce. Tyto články podrobili obsahové analýze a zjistili, že se ve sledovaném období měnil zájem badatelů i odborníků - čtenáŕů časopisu. Identifikovali čtyři tematické okruhy, které šly $\mathrm{v}$ tomto pořadí: předpokládaná možnost škálování změn ve školství ( $v$ širokém i lokálním měřítku); důraz na rovnost šancí a na kontextové, prostorové a geografické aspekty reforem; výzkum $\mathrm{v}$ rámci projektu PISA a konvergování nálezů, které přinesl; anglo-americký pesimismus plynoucí z výsledků školské politiky a neúspěšných školských reforem; počínající internacionalizace a důraz na solidní empirické výzkumy.

Domníváme se, že tématem, které se stává výzkumně důležitým právě $\mathrm{v}$ této době, je odpor části učitelů vůči změnám ve školství. Důležitost zkoumání jevu, který můžeme popsat jako nedůvěru, kritizování či dokonce odporování změnám ze strany učitelů, kontrastuje $s$ aktuální situací: v naší republice se tímto jevem vědecky zabývá (vedle své hlavní činnosti) jen několik jedinců. Tvůrci, manažeři a prosazovatelé změn $\mathrm{v}$ českém školství př́liš nesledují, co běžní učitelé o změnách vědí, jak je přijímají a prožívají, jak se s nimi vyrovnávají, jak si je modifikují a které dlouhodobé účinky změny reálně přinášejí. Proto jsme se pokusili shrnout názory domácích odborníků a výsledky zatím skromných domácích výzkumů. Současně jsme se zajímali o to, jak je tato problematika rozpracovávána $\mathrm{v}$ zahraničí a k jakým zjištěním badatelé dospěli v zemích, které jsou nám ze sociokulturního pohledu blízké. Provedli jsme prríslušnou 
rešerši a získané poznatky jsme zpracovali do přehledové studie.

Rešerši jsme uskutečnili $\mathrm{v}$ těchto databázích: PsyARTICLE, Academic Search Complete, ERIC, OVID, EBSCO. Volili jsme časové období 1978-2018 a citace jsme hledali pomocí těchto klíčových slov: „resistance to change“ AND teacher AND school AND education. Rešerše identifikovala 574 prací. U získaných citací jsme se primárně soustředili na práce po roce 1990. Ze starších prací jsme vybrali pouze ty, které byly často citovány. Získané práce jsme prošli podle názvů a abstraktů. Vyřadili jsme editorialy, dopisy redakci, popularizující články a zprávy. Při výběru článků z akademických časopisů jsme preferovali texty obecnější povahy. Rešerši z uvedených databází jsme ještě doplnili ruční rešerší ve vyhledávači Google. Nezařadili jsme práce, které sice popisovaly výzkumy odporu vůči změnám ve školství, ale v zemích s velmi odlišnými sociokulturními podmínkami. $V$ této přehledové studii pracujeme se 59 zahraničními pracemi.

Které cíle si tato přehledová studie klade? Jsou čtyři: 1. přibližit pojem změna a na př́kladech ilustrovat rozdílné úrovně školského systému, na nichž mohou změny ve školství probíhat, 2 . upozornit na obtíže spojené s definováním pojmu „odpor učitelů vůči změně“ a ukázat nejen negativní, ale také pozitivní stránky takového odporu, 3. podat přehled faktorů, které se spolupodílejí na podporování změny i faktorů posilujících odpor učitelů vůči změnám, 4. přibližit metody, jimiž se dá odpor učitelů vůči změnám zjištovat. $V$ naší studii jsme akcentovali psychologický pohled na odpor učitelů (jako jednotlivců i skupin) vůči změnám ve škole i ve školství.

\section{ProblémY S POJMEM „ZMĚNA“}

Jsou v zásadě dvojího druhu a jsou navzájem propojeny: jde o problémy věcné a problémy terminologické. Pojem změna je na první pohled jasnou záležitostí, nebot výraz změna je lidem intuitivně srozumitelný. Uvědomme si však, že odborný pojem změna je významově neutrální: může existovat změna jak $\mathrm{k}$ lepšímu, tak $\mathrm{k}$ horšímu. Kromě valence změny však záleží i na její velikosti, rozsahu a hloubce. Štech říká: Některé změny ani nevnímáme jako bůhvíjaký zlom, považujeme je za evoluční a "přirozené" (Štech, 2014, s. 102). Všimněte si prvního slovesa: autor upozorňuje, že jde o (subjektivní) vnimání změny, což znamená, že pohled různých lidí na tentýž zásah, na tutéž intervenci se může lišit.

Změny $\mathrm{v}$ českém školství probíhaly a stále probíhají na různých úrovních školského systému. Odlišují se tedy svým rozsahem a dopadem, liší se hlavními iniciátory změn i směrem zavádění: ve které instituci se zrodily (např. MŠMT, krajský úřad, obec, učitelská asociace), jakou právní podobu mají a komu jsou primárně adresovány.

Po roce 1989 zažili naši učitelé a školy různých typů a stupňů řadu změn. Přehled navržených a $\mathrm{v}$ různém rozsahu započatých reforem, které probíhaly převážně „zespodu“, tj. od učitelů, od učitelských iniciativ, shrnuje monotematické číslo časopisu Pedagogika 4/1998. Vyšlo v editorství 
Vl. Spilkové pod názvem Reformni trendy $v$ českém školstvi 90. let.

Kromě změn „zespodu“ probíhaly po roce 1989 v českém školství i změny, které bychom označili jako změny prosazované „shora“. Píšová et al. (2013, s. 192) mluví o externě vnucených (top-down) edukačních změnách.

Př́íkladem jsou koncepční změny na úrovni celého školství. Zmiňme alespoň některé. $\mathrm{V}$ devadesátých letech došlo ke změně českého školského systému. Zákon umožnil vznik škol, které zřizují soukromé osoby, společnosti nebo církve; vznikla víceletá gymnázia, vyšší odborné školy a integrované střední školy. Jedním $\mathrm{z}$ nepríznivých důsledků těchto změn je vysoká míra selektivity školského systému na úrovni povinného vzdělávání. Řada rodičů má tendenci vytvářet pro své děti exkluzivní prostředí (zejména ve víceletých gymnáziích). Vysoký počet víceletých gymnázií teprve $\mathrm{v}$ posledních letech vyvolal diskusi v laické i odborné veřejnosti, takže politici začínají debatovat o snížení tohoto počtu, ale bez znalostí dopadu takového rozhodnutí (Audit, 2017, s. 10).

Počínaje rokem 2001 započala zásadní změna pregraduální prŕpravy učitelů základních a středních škol v duchu Boloňské deklarace o vysokých školách (novela vysokoškolského zákona č. 147/2001 Sb.). Na pedagogických fakultách a všech dalších fakultách připravujících učitele se rozběhlo strukturování učitelského studia do dvou stupňů: bakalářského studia a navazujícího magisterského studia. Základem změny celého systému př́pravy učitelů bylo politické rozhodnutí, a proto se účinnost nového systému a jeho dopady nevyhodnocovaly, i když učitelé vysokých škol měli řadu výhrad (podrobnosti o průběhu zavádění změn viz např. Mareš, 2013).

Jiným př́kladem celostátní koncepční změny je prodloužení povinné školní docházky o jeden rok v rámci posledního roku v mateřské škole, a to počínaje zárím 2017. Tato změna byla zavedena, i když existuje studie proveditelnosti, která upozorňuje na závažné problémy, které změna přinese (Hůle, Kaiserová, Kabelová et al., 2015).

Nešlo jen o velké koncepční změny. $\mathrm{Na}$ celostátní úrovni se uskutečnily i velké organizační změny. $V$ roce 2011 z rozhodnutí ministra J. Dobeše došlo ke sloučení Výzkumného ústavu pedagogického v Praze (VÚP), Národního ústavu odborného vzdělávání (NÚOV) a Institutu pedagogicko-psychologického poradenství (IPPP); bez předchozí studie proveditelnosti a bez následného vyhodnocení změn. V letech 2015-2017 neměl NÚV stabilní vedení, docházelo $\mathrm{k}$ výrazným strukturálním a personálním změnám ústavu bez transparentní analýzy a zdůvodnění. O efektivitě fungování NÚV a dalších podpůrných organizací nejsou $\mathrm{k}$ dispozici přesvědčivé doklady (Audit, 2017, s. 13).

Jinou skupinu změn tvoří organizační změny na regionální úrovni. Zákon o státní správě a samosprávě ve školství byl novelizován v letech 2001-2004. Novelizace dodala krajům a některým obcím impuls ke změnám $\mathrm{v}$ dosavadní síti škol a školských zařízení. Důsledkem bývá nejen slučování škol stejného typu (zejména 
středních škol), ale také slučování škol různých typů (např. slučování základní školy $s$ mateřskou). O průběhu "optimalizace“ sítě škol máme $\mathrm{k}$ dispozici jen dílčí výzkumné sondy. Týkají se nejen slučování škol (Trpišovský, 2007; Novotná, 2011), ale i rušení škol (Plachá, 2008). J. Pelikán (2012) připomněl, že nedomyšlené rušení škol v mnoha obcích mívá za následek nejen zhoršení podmínek pro žáky, kteří musejí dojíždět jinam, ale i pro samotnou obec. Závažným dlouhodobým důsledkem je, že rodiče se $s$ dětmi stěhují do větších obcí a vesnice bez školy se začínají vylidňovat. Finanční úspora za provoz školy má za následek ztráty mnohem větší.

Zbývá nám ještě skupina, která zahrnuje organizační a procedurální změny na úrovni jedné školy. Po věcné stránce se dílčí sondy snaží o studium hlubších dopadů změny ve vedení školy (Kopárek, 2007), změny v administrativním vykazování informací o fungování školy (Novotná, 2011) či změny v postupech při výchově a vzdělávání žáků (Novotná, 2011).

\section{Problémy s PojMem „ODPOR VƯČI ZMĚNĚ}

Ke změnám, které probíhají na různých úrovních školského systému, zaujímají učitelé hodnoticí stanovisko jako jednotlivci či skupinky učitelů, anebo jako celý učitelský sbor. Dále jako učitelé určitého vyučovacího předmětu a/nebo učitelé určitého stupně a typu školy. Zmíněné hodnoticí stanovisko lze operacionalizovat různým způsobem. Můžeme použít psychologický pojem postoj ${ }^{2}$ (viz např. Kohnová, 1995; Beran, Mareš ml. \& Ježek, 2007; Mohamedová, 2008; Zelená, 2011; Hůle, Kaiserová, Kabelová et al., 2015). Postoj mívá tři základní podoby (je kladný - neutrální - záporný) s jemnějšími přechody mezi nimi nebo $s$ různými kombinacemi (viz např. ambivalentní postoje). Anebo můžeme použít odlišný pojem profesní presvèdčeni učitelù (beliefs) týkající se navrhované či realizované změny (Straková, Spilková, Friedlaenderová et al., 2014).

Nejdelší tradici má ovšem pojem, který vyjadřuje nesouhlas se změnou, tj. vzdorování, odporování změně. Beran et al. (2007) mluví o nesouhlasném reagování na změnu. $\mathrm{V}$ angličtině má podobu resistance to change. Právě tento pojem je jádrem naší přehledové studie. Jev, který tento pojem označuje, se zkoumá dlouho, už sedmdesát let, ale zpočátku nikoli ve školství. První práce na toto téma se objevily krátce po skončení 2 . světové války, a to $\mathrm{v}$ rámci psychologie práce a organizace (Coch \& French, 1948). Autoři, jak sami $\mathrm{v}$ úvodu uvádějí, vydatně čerpali z prací sociálního psychologa Kurta Lewina. Zpočátku se jejich následovníci zabývali sociálními procesy $\mathrm{v}$ organizaci jako celku (odporování jako obranný mechanismus, sociální dopady takového mechanismu), zatímco individuální aspekty zůstávaly dlouho stranou. Teprve kolem roku 2000 se jim začala věnovat odborná pozornost,

\footnotetext{
${ }^{2}$ Postojem rozumíme hodnoticí vztah, vyjádřený sklonem reagovat ustáleným způsobem na předměty, osoby, situace a na sebe sama. Postoje předurčují poznání, chápání, myšlení a cítění lidí. Jsou relativně trvalé a obsahují složku poznávací, citovou - afektivní a konativní - behaviorální (Hartl \& Hartlová, 2010, s. 431).
} 
zejména pak aspektům afektivním, kognitivním a behaviorálním.

$\mathrm{V}$ naší přehledové studii se zajímáme o výhrady učitelů ke změnám ve školství, o odporování změnám v pedagogickém kontextu; jeho aktéry jsou učitelé jako jednotlivci či skupiny a/nebo celé učitelské sbory. Ponecháváme stranou pracovníky školské správy, ředitele, rodiče žáků a studentů, profesní asociace a sdružení. Stranou ponecháváme i další zajímavá témata, např. management zavádění změny, řízení změny ve škole (Slavíková, 2008), možné intervence proti projevům nesouhlasu se změnami a hodnocení účinnosti samotné změny.

Situaci nám komplikuje fakt, že odporování změnám nemůže být studováno $s$ oporou o poznatky jednoho vědního oboru, nýbrž jde o transdisciplinární záležitost (Clark, 2013). Na zkoumání odporu se podílejí mj. tyto obory: školský management, sociologie, sociální psychologie, psychologie práce a organizace, psychologie osobnosti a pochopitelně pedagogika. $\mathrm{Z}$ toho plyne, že odpor vủči změně nemá jednu dimenzi, ale mnoho dimenzí - jde tedy o multidimenzionální jev (Ansof, 2007). Jak už jsme uvedli výše, v této studii akcentujeme především psychologický pohled.

Jako východisko našeho př́stupu přijímáme základní rozlišení Bauera (1993), který říká, že kritizování změn, odporování změnám představuje neoficiální, skryté jednání pracovníků dané organizace. Oproti tomu existují oficiální protesty, které $\mathrm{v}$ rámci dané instituce vyhlašují organizace, jež pracovníky zastupují při jednání $s$ vedením organizace. Tyto protesty musí respektovat platnou legislativu. $V$ této studii se budeme věnovat pouze neoficiálnímu, implicitnímu dění ve školách.

Výše jsme uvedli, že odborný termín pro nesouhlas se změnou, kritizování změny, odporování změně má $\mathrm{v}$ angličtině podobu resistance to change. Není však snadné ho přeložit do češtiny a to nejméně ze dvou důvodů - věcných a kontextových.

Věcně vzato anglický psychologický pojem resistance má tři odlišné významy. Může jít o:

a) vlastnost osobnosti, osobnostní rys (odolnost jedince);

b) obecný děj, proces - projevování nesouhlasu či vzdorování, bránění něčemu nespecifikovanému;

c) výsledek procesu, jímž se zvyšuje odolnost člověka (výsledek zvládání zátěžových situací, výsledek psychologického nebo fyzického výcviku).

$\mathrm{V}$ našem př́ípadě $\mathrm{k}$ těmto třem významům přistupuje ještě čtvrtý:

d)specifický děj, proces, jímž se člověk snaží zabránit konkrétní změně - změně týkající se školství nebo školy jako instituce, ${ }^{3}$ a tím i učitelů samotných.

Bylo by jistě možné (jak to ostatně doporučoval jeden $\mathrm{z}$ anonymních recenzentů) použít $\mathrm{v}$ této studii počeštěnou variantu anglického termínu a zvolit výraz rezistence vi̊č zmèně, jak to učinila napr. Lazarová (2005a, 2005b).

\footnotetext{
${ }_{3}^{3}$ Přikláníme se - ve shodě s Dvořákem et al. (2010, s. 1) - k rozlišování školy jako obecné instituce na jedné straně a jednotlivými konkrétními organizacemi, tj. fyzicky existujícími školami, na straně druhé.
} 
Domníváme se však, že bychom tím ignorovali druhý aspekt problému, kterým je domácí kontext. $\mathrm{V}$ jiných vědních oborech je už zaveden český výraz „odpor ke změně“ či „odpor vưči změně“ a má své pevné místo v odborné literatuře. Uved’me výběrově tyto vědní obory: management (Smejkal \& Rais, 2013), psychiatrie (Soukup, 2011), ošetřovatelství (Herdman, 2013), sociální služby (Furmaníková et al., 2013). Nejvhodnější by bylo v češtině používat výraz, který by naznačil celou škálu nesouhlasu a současně se př́liš nevzdálil od zavedeného českého termínu, viz např. výraz „opozice až odpor vůči změně“. Složený výraz je však stylisticky obtížně použitelný, a proto $\mathrm{v}$ této studii zůstaneme u zavedeného výrazu „odpor vůči změně“.

Nemálo autorů se snažilo tento jev přesněji definovat, ale zatím jde o dílčí pohledy; dosud neexistuje jedna všeobecně přijímaná definice. $\mathrm{V}$ předkládané studii definujeme odpor učitelů vůči změně takto: Jde o afektivní, kognitivní a behaviorální reagování učitelů, které má za cíl udržet status quo. Učitelé se snaží zastavit, oddálit nebo modifikovat navrhované změny. Učitelé tak jednají $\mathrm{v}$ př́ípadech, kdy vnímají, že změna, která nastává, je pro ně hrozbou. Klíčovými slovy v této definici jsou „vnímání" a „hrozba“. Nemusí tedy jít ani o reálnou, ani o závažnou hrozbu. Jejich pohled na změnu však nebývá statický ani homogenní (viz např. ambivalentní postoje ke změně), ale proměňuje se $\mathrm{v}$ čase (modifikovaně podle Berkovich, 2011; Chaining Minds, 2018).

Uvedená definice vyžaduje komentár. $\mathrm{V}$ mnoha prrípadech, jak ukazuje např.
Pideritová (2000), jsou postoje pracovníků $\mathrm{k}$ navrhovaným změnám rozporné, tj. $\mathrm{k}$ některým aspektům změny zaujímají pozitivní, $\mathrm{k}$ jiným neutrální a $\mathrm{k}$ dalším zase negativní postoj. Další autoři dodávají, že postoj pracovníků ke změně nemá jenom valenci (je negativní - lhostejný - pozitivní), ale svůj psychologický obsah. Mưžeme rozlišit postoje, $\mathrm{v}$ nichž dominují bud' emoční/afektivní, nebo kognitivní, anebo konativní/snahové aspekty (Výrost, 1989). Tato trojice se také podílí na ambivalentnosti výsledného postoje.

Z psychologického pohledu není vhodné dívat se na odpor vůči změně jednostranně: dobří jsou ti učitelé, kteří brání fungující systém, dlouholeté zkušenosti, zformované mezilidské vztahy; špatní pak ti, kteří bez hlubší analýzy aktuálního stavu prosazují málo vyzkoušené postupy a nedbají na postoje těch, kteří mají změnu realizovat. Nebo naopak: dobř́ jsou ti učitelé, kteří prosazují změnu rutiny, a špatní ti, kteří o účelnosti změny pochybují, nesouhlasí s ní. Ve skutečnosti - jak upozorňují Ford a Fordová (2010) - jde o vzájemnou interakci obou skupin ( $\mathrm{tj}$. př́znivců i odpůrců), přičemž každá skupina reaguje na to, jak se chová ta druhá.

Negativní aspekty odporu. Podle aktérů prosazujících změnu je odpor učitelů chápán jako hrozba dobře míněným snahám o zlepšení celkové situace, jako brzda pokroku, jako dysfunkční úsilí, na jehož překonání bude třeba vynaložit zbytečnou práci navíc. Odpůrci změn jsou pro ně překážkami, nikoli potenciálními partnery (Ford \& Fordová, 2010). Podle Thomase a Hardyové (2011) někteří prosazovate- 
lé změn pojímají odpor pracovníků jako něco, čemu je zapotřebí se vyhnout, anebo - pokud je príliš silný - co je třeba vymýtit. Deneen a Boud (2014) charakterizují odpor vůči změně jako snahu pracovníků zabránit změně, nebot́ ji chápou jako záležitost, která lidi omezuje; svazuje je formálními postupy, posiluje jednostranný pohled na problémy a prosazuje rigidní chování. Bolognese (2002) připomíná, že ti, kdo nesouhlasí se změnami a mají řadu dotazů a připomínek, jsou svými nadřízenými chápáni jako osoby odpírající poslušnost.

Pozitivní aspekty odporu. Úspěšnost či neúspěšnost změny lze zhodnotit obvykle až poté, co proběhne. Pak teprve můžeme zjistit její reálné důsledky, at už krátkodobé, nebo dlouhodobé. Ty pochopitelně nemůžeme $s$ jistotou znát předem. Zatímco vnější tlaky i aktéři změny v organizaci povzbuzují pracovníky $\mathrm{k}$ zavádění změn, odpor vůči změnám je faktor, který tento pohyb vyrovnává $s$ potřebou organizace fungovat bez výkyvů (Waddellová \& Sohal, 1998). Odpor vůči změnám tedy udržuje stabilitu systému a brání povrchním, nedomyšleným změnám, nekriticky prijímaným inovacím. Deneen a Boud (2014) konstatují, že odpor vůči změnám může být považován za očekávanou, a dokonce žádoucí kvalitu, za projev iniciativy lidí. Aktivní odpor vůči změnám naznačuje, že lidé o změnách přemýšlejí, ptají se na podrobnosti, zajímají se o důsledky změn. Podle Bolognese (2002) mohou pracovníci, kteří se změnou hned nesouhlasí, sehrát pozitivní roli. Mohou iniciovat debatu, která půjde do hloubky a bude usilovat o to, aby se všichni zúčastnění dobrali podstaty změny. Kritický pohled na změnu by neměl být ztotožňován $s$ úplnou negací změny, pokud ovšem obě strany hledají cestu, jak dospět k nejlepší variantě změny pro dané podmínky. Podle Thomase a Hardyové (2011) může management organizace nalézt $\mathrm{v}$ dotazech, které cílí na výchozí předpoklady změny nebo na vysvětlení jednotlivých kroků při zavádění změny, důležité podněty na $v y$ lepšení původní podoby změny. Podle Forda a Fordové (2010) lze odpor analyzovat, pochopit a využít ke zlepšení celého procesu zavádění změny, nebot' odpor má svou hodnotu. Přinejmenším nutí ty, kdož změnu prosazují, aby se vrátili na začátek, znovu promysleli účel změny a vyvodili $\mathrm{z}$ komplikací poučení. Jinak řečeno: odpor ke změně může změnu změnit $\mathrm{k}$ lepšímu.

Dynamické aspekty odporu. V mnoha publikacích je odpor pracovníků vůči změně chápán jako konstantní a v podstatě neměnná záležitost. Na základě tohoto pohledu jsou pak pracovníci rozdělováni na příznivce a odpůrce změny. Ve skutečnosti je odpor vưči změně dynamický konstrukt, přičemž jeho afektivní, kognitivní i behaviorální složky se proměňují v čase. Odpor obvykle mívá rozporný charakter; $\mathrm{v}$ některých aspektech blokuje zavádění změn, $v$ jiných může naopak změnám napomáhat. Odpor vůči změně lze modifikovat během opakované komunikace mezi agenty změny a jejími odpůrci. Při vhodně koncipované komunikaci se odpor tlumí, ale při nevhodné přesvědčovací strategii může být naopak posilován (bliže viz např. Klonek, 2014). 
FAKTORY PODPORUJÍCí ZMĚNU

\section{A FAKTORY BRÁNÍCÍ ZMĚNĚ}

V odborné literatuře se používá rozdílná terminologie: mluví se o príćčinách odporu ke změně (Ženka, 2007, s. 17), o antecedentech odporu ke změně (Khan \& Rehman, 2008), o silách odporujících změně (Khan \& Rehman, 2008; Bowers, 2011), o zdrojích odporu vůči změně (Val \& Martínez-Fuentes, 2003). V tomto oddíle budeme použivat termín faktory podporující změnu / bránící změně.

\section{Faktory podporující změnu}

Náš výklad začneme krátkým přehledem faktorů, které usnadňují změnu ve školách a ve školství a podporují ji. Můžeme o nich v zásadě uvažovat na třech úrovních: individuální, školní a celospolečenské.

$\mathrm{K}$ individuálním faktorům lze zařadit tři osobnostní charakteristiky, jimž se věnuje pozornost až $\mathrm{v}$ poslední době. $\mathrm{V}$ rámci teorie kognitivní adaptace se objevil pojem otevřenost ke změně (openness to change). Wanberg a Banas (2000) jím rozumějí skutečnost, že jednotlivec se vyznačuje optimismem, vysokou sebedůvěrou a pocitem, že má průběh událostí pod kontrolou. I během stresující události si zachovává vysokou úroveň pohody. Tento pojem se používá napřr. pro důkladnější studium toho, jak se jednotliví pracovníci vyrovnávají s reorganizací svého pracoviště. Obdobným pojmem je připravenost ke změně (readiness to change). Holt, Armenakis, Harris et al. tuto pripravenost definují následovně: jde o komplexní postoj jedince nebo skupiny, který je ovlivňován obsahem změny, jejím kontextem a také zvláštnostmi jednotlivců, kterých se změna týká. Ve svém souhrnu odrážejí rozsah, ve kterém jsou jednotlivec nebo skupina nakloněni souhlasit se změnou, přijmout ji za vlastní a podílet se na zavedení konkrétního plánu, který promyšleně změní dosavadní status quo (Holt et al., 2007, s. 326).

Relativně novým pojmem, který vychází z pozitivní psychologie, je pojem akceptování, príijímání změny (acceptance of change). Di Fabiová a Gori ho definují jako tendenci přijímat změnu, nikoli se jí vyhýbat, protože její akceptování je př́íznivé pro jedincův pocit pohody. Akceptování změny vychází z přesvědčení, že jedinci, kteří jsou schopni ve své práci a jiných činnostech prrijímat změny, často zjištují, že změna má pozitivní dopad na jejich pracovní život a úroveň jejich zdrojů (Di Fabiová \& Gori, 2016, s. 1).

$\mathrm{K}$ faktorům na úrovni školy, které napomáhají změnám, lze zařadit (modifikovaně podle Lunenburg, 2010): tlak vedení školy na zlepšení klimatu školy, komunikace a spolupráce uvnitř učitelského sboru, strategie vedení zvyšující motivaci učitelů lépe vyučovat. Zdá se, že v počáteční fázi zavádění změny napomáhá změně klima školy, které se vyznačuje flexibilitou, soudržností a důvěrou, zatímco $\mathrm{v}$ konečné fázi je výhodnější klima, pro něž je charakteristická stabilita, kontrola a řízení, plánování, stanovování cílů. Souhrnně řečeno s Alharbim et al. (2012): organizace, která dokáže citlivě vyvážit odlišné proti- 
kladné charakteristiky obou organizačních kultur (flexibilita-stabilita), má větší šanci na úspěšné zavedení změny i na její dlouhodobé udržení. Změně napomáhá - paradoxně - i opak právě uvedeného: dlouhodobé problémy s klimatem školy, obtížná spolupráce $\mathrm{v}$ učitelském sboru, nevhodné způsoby motivování učitelů, nedostatek kvalifikovaných učitelů, jakož i problémy s prospěchem a chováním žáků školy, složité vztahy školy s komunitou, v níž působí. To vše ve svém úhrnu donutí vedení školy i učitelský sbor tyto problémy řešit.

Celospolečenské faktory se pokusili charakterizovat $\mathrm{v}$ USA Brand a Johnson (2001) v článku Sily podporujici zménu: škola $v$ novém tisíciletí. $\mathrm{V}$ jejich závěrech jsou uvedeny tyto facilitující vlivy. Rozšrirí se prý chápání toho, co spadá pod pojem edukace. Výchova a vzdělávání se budou odehrávat $\mathrm{v}$ mnohem větší míře i mimo prostory škol. Bude vzrůstat heterogenita žáků, včetně podílu dětí z minorit a imigrantů. Stoupne podíl soukromých škol a domácího vzdělávání. Zvýsí se důraz na standardy pedagogické činnosti, na efektivitu a akontabilitu. Dojde k redistribuci finančních aj. zdrojů pro výchovu a vzdělávání. Ve školství bude narůstat tendence $\mathrm{k}$ centralizaci rozhodování. Dodejme, že jde o zobecnění trendů, jak je autoři článku vnímali na počátku třetího tisíciletí v USA.

Pokud jde o samotný resort školství, odborníci rozdělují faktory, které podporují změny, do dvou skupin. $K$ vnějším faktorům, které změny ve škole usnadňují, patř́ podle Lunenburga (2010) tyto:

- školské legislativní dokumenty, které školy zavazují, aby do určitého data změnu připravily a od určitého data začaly zavádět;

- konkurence jiných škol v dané lokalitě: aby škola přežila, musí mít dostatek žáků;

- informační a komunikační technologie: sociální sítě umožňují porovnávat školy mezi sebou včetně výhod, které pro žáky školy a jejich rodiče nabízejí; počítače umožňují nové formy učení;

- pracovní trh: záleží na lokalitě školy, na její pověsti a možnostech, které škola svým stávajícím či budoucím pracovníkům nabízí. Tento parametr je zvlášt důležitý v období, kdy je málo kvalifikovaných učitelů a málo učitelů v produktivním věku;

- ekonomické tlaky, které determinují snahu škol fungovat co nejlépe, získávat sponzory, umožnit takové typy mimoškolních aktivit žáků, které jiné školy nemají.

Uvedli jsme faktory, které usnadňují změny ve školách a školství a nyní je čas věnovat se hlavnímu tématu naší studie faktorům, které změnám brání.

\section{Faktory komplikující změnu až zabraňující změnám}

Jde o faktory, které odpor vůči změně výrazně podporují či alespoň $\mathrm{k}$ němu významně přispívají. Nahlédnutí do odborné literatury ovšem ukazuje, že vytvořit zdůvodněný přehled intervenujících faktorů není snadné. $\mathrm{Na}$ dané téma jsme nenašli žádnou meta-analýzu a mnohé dílčí přehledy obvykle nemají jasnou strukturu. Navrhli jsme proto sami deset níže uvedených hledisek. 
Faktory související se zvláštnostmi učitele samotného. K těmto faktorům patří odpor ke změnám jako dispoziční rys učitelovy osobnosti, tedy jeho tendence stavět se negativně vůči všemu, co mění status quo; dále je třeba zmínit kognitivní rigiditu, tj. neochotu poznávat něco nového (Oreg, 2003). Specifickou proměnnou je učitelova vnímaná vlastní pedagogická zdatnost (self-efficacy). Výzkumná sonda Gonsiewského (2014) konstatovala paradox: čím více si učitel po pedagogické stránce věŕí, čím víc si je jistý, že problémy se žáky a učivem zvládne sám, tím méně je ochoten přijmout doporučované změny.

Za zmínku stojí, že k obdobnému zjištění dospěl český výzkum u učitelů-expertů. U nich se objevovalo relativně kritické nahlížení na obecně uznávané vzdělávací trendy (např. výuka zaměřená na žáka, diferenciace ve výuce, inkluzivní vzdělávání) a jejich často populistické prosazování (Píšová et al., 2013, s. 191-192).

Pokud jde o afektivní rovinu, lze uvést učitelův strach $\mathrm{z}$ neznámého, ale i ohrožení jeho potřeby bezpečí a jistoty (Yilmaz \& Kitiçoglu, 2013) či strach z rizika (Mutchler, 1990; Lazarová, 2005a). Objevují se také obavy učitele z omezení či ztráty dosavadní svobody jednání, autonomie (Yilmaz \& Kitiçoglu, 2013). Širší pohled na škálu emocí, které učitel prožívá, přináší např. kvalitativní sonda u holandských učitelů (Van Veen \& Sleegers, 2006).

Bývá běžné, že v učitelském sboru jsou zastoupeny tř̀i generace učitelů: mladí učitelé, učitelé středního věku a staří, zkušení učitelé. Jejich postoje ke změnám jsou ovlivněny nejen osobními zvláštnostmi, ale také osobními zkušenostmi s řadou předchozích reforem školství. Lazarová (2005b) upozorňuje, že zejména u starší generace bývá nedůvěra $\mathrm{v}$ jakékoli změny uložena velmi hluboko a tito učitelé předávají své negativní zkušenosti mladším generacím.

Ruschová a Perryová (1993) připomínají výzkum Hubermana z počátku 80 . let, který zjistil, že u starších, zkušených učitelů se objevuje tendence stáhnout se do sebe, nezapojovat se do zavádění inovací a reforem. Tito učitelé charakterizovali sami sebe jako lidi, kteří už nejsou ochotni investovat mnoho úsilí do své kariéry, nechtějí se angažovat $\mathrm{v}$ reformních snahách. Novější výzkumy však dospívají k jinému, zřejmě realističčějšímu závěru: zkušení učitelé, kteři dospěli do závěrečné fáze své profesní kariéry, netvoří homogenní skupinu a na změny ve školství reagují diferencovaně (Snyder, 2017).

Faktory související s pedagogickou činností učitele. Ignorování učitelovy pedagogické autonomie vyvolává u učitelů vnitřní odpor vůči prosazovaným inovacím (Knight, 2009). Existují i situace, kdy nové myšlenky o změně nejsou učitelům podány tak, aby bylo patrné, v čem je jejich reálný př́nos, zda jsou uvažované postupy použitelné v běžné praxi (Baum, 2002; Terhart, 2013). Učitelé se někdy obávají, že avizovaná změna je jen startem $\mathrm{k}$ něčemu většímu a hlubšímu, na co už oni nebudou stačit (Lazarová, 2005b), že jim budou chybět potřebné nové dovednosti (Mutchler, 1990). Reforma zpravidla nutí učitele k zásadnímu restrukturování pedagogické činnosti (Gitlin \& Margonis, 1995). 
Faktory související se sociálním postavením učitele. Jde např. o ohrožení dosavadní moci učitele, která je dána jeho funkcemi. Ve hře může být také jeho obava ze ztráty svého neoficiálního vlivu v učitelském sboru (Yilmaz \& Kitiçoglu, 2013). Učitelé se bojí změny své sociální role po zavedení reformy a s tím spojené vyšší odpovědnosti (Mutchler, 1990).

Faktory související se zvláštnostmi žáků. Těžko je učiteli zavádět nějaké změny do výuky, když mnozí žáci doma slyší, že vzdělání není potřeba, a proto zaujímají ke škole negativní postoj; nepřipravují se na výuku a neumějí se chovat (McKenzie $\&$ Scheurich, 2008). Problémem také bývá situace, kdy je struktura školních trríd výrazně heterogenní a reformní snahy tlačí učitele $\mathrm{k}$ tomu, aby při výuce zajistili pro všechny žáky sociálně spravedlivé podmínky a kulturně citlivé zacházení.

Typickým př́kladem je situace na Novém Zélandu, kde $\mathrm{v}$ jedné třídě jsou dvě odlišné etnické a sociální skupiny - děti $\mathrm{z}$ maorských rodin a děti $\mathrm{z}$ rodin evropského původu. Tvůrci reformy nepočítali $s$ tím, že učitelé budou zažívat dvojí tlak: ze strany rodin evropského původu obavy, že jejich děti budou mít horší príležitost se vzdělávat, protože se výuka bude přizpůsobovat maorským dětem; ze strany maorských rodin strach, že výuka preferuje kulturní hodnoty majoritní společnosti a ohrožuje kulturní identitu jejich dětí (Hynds, 2010). Analogie bychom našli i u nás.

Faktory související se sociálním vztahy ve sboru a ve škole, $s$ klimatem školy. Př́ílady: Změna může zrušit dosavadní organizační uspořádání školy a zavést nové, nezvyklé (Yilmaz \& Kitiçoglu, 2013). Změna může narušit jemnou rovnováhu, které bylo v kultuře školy dosaženo (Lazarová, 2005b). Kurikulární změny vyžadují od učitelů úzkou vzájemnou spolupráci a $\mathrm{v}$ mnoha prípadech také sdílené rozhodování, což se neobejde bez mezilidských konfliktů (James \& Jones, 2008). U starších učitelů se objevuje specifický důvod $\mathrm{k}$ odporu: prosazované reformy v řadě př́ipadů naruší dosavadní dobré mezilidské vztahy ve sboru, což senioři těžce nesou; objevuje se u nich také odpor motivovaný tzv. sociální nostalgií po lepší minulosti (Snyder, 2017).

Faktory související s vedením školy. Někteří vedoucí pracovníci školy podávají důvody pro změnu ve škole či ve školství učitelům tak, že používané argumenty vyznívají jako kritika celé dosavadní pedagogické práce učitelů; to učitele zraňuje a nutí $\mathrm{k}$ nesouhlasu (McKenzie \& Scheurich, 2008). Vedení školy bývá pod tlakem nadřízených orgánů, aby urychleně zavádělo změny a vykazovalo inovace. Učitelé by se některým změnám nebránili (pokud by probíhaly v klidu a postupně), ale bývají uštváni rychlým sledem změn (Lazarová, 2005b). Kromě rychlosti změn je rizikem i velký počet dílčích změn, které jsou v dané škole zaváděny. Trvalý pracovní stres zpravidla vyústí ve stav, který se odborně označuje jako únava ze změn (Bernerth, Walker \& Harris, 2011). Tento specifický typ únavy má závažné negativní dopady. Navozuje psychickou nejistotu, dostavuje se emoční vyčerpání, neochota až odpor ke změnám; učitelé zvažují od- 
chod ze zaměstnání. Existuje také rozdíl mezi tím, co chce či potřebuje management školy a co chtějí učitelé, kteří mají ve změněné situaci žít (Lazarová, 2005b).

Faktory související $s$ materiálním a finančním zabezpečením. Pokud jde o školu jako celek, může změna odhalit omezenost zdrojů, s nimiž může škola počítat (Yilmaz \& Kitiçoglu, 2013), nebo neadekvátnost či nevhodnost zdrojů, z nichž lze při zavádění reformy čerpat (Mutchler, 1990). Nezanedbatelné jsou také obavy učitelů, že změna přinese změnu jejich pracovního zařazení, a tím i zhoršení jejich finanční situace.

Faktory související s koncepcí zavádèné změny. Prosazovaná změna může stavět na hodnotách, s nimiž nejsou řadoví učitelé ztotožněni, nebo s nimi dokonce vnitřně nesouhlasí (Hambrick \& Canella, 1989). U starších učitelů v USA se objevuje specifický důvod, proč se staví ke změnám ve školství negativně: zažili období, kdy měli učitelé ve své práci relativně velkou autonomii, a ta se nyní centralizačními tlaky vytrácí; proto se u nich objevuje odpor motivovaný tzv. (školně) politickou nostalgií po starých časech (Snyder, 2017). Pideritová (2000) říká, že neuctivý postoj pracovníka vůči změně může být motivován rozporem mezi prosazovanou změnou a etickými principy, jež pracovník zastává, či snahou ochránit to, co jedinec považuje pro své pracoviště za nejlepší.

Zaváděná změna může klást na běžné školy nerealistické požadavky. Mưže navozovat v učitelích úzkost, že se po nich chce něco, co i při sebevětším nasazení nemůže dobře fungovat, a laici pak budou neúspěch přičítat jim (Baum, 2002; Terhart, 2013). Při prrípravě změny ve školství se totiž nedá všechno předvídat ani naplánovat. Používané manažerské modely změny nebývají adekvátní složitosti reality, a proto se během uskutečňování změn ve školské praxi zákonitě vyskytnou nepředvídané události (Trubowitz, 2001). Celý vzdělávací systém je mnohoúrovňový a těžko může být jako celek řízen přesnými cíli. Školský systém zahrnuje víceúčelová vzdělávací a výchovná zařízení, která mají také svou vnitřní vývojovou dynamiku. Ta je může v některých př́padech měnit rychleji než jakákoli reforma prosazovaná zvenčí (Terhart, 2013).

Faktory související $s$ používanými postupy při zavádění změny. Praktické zkušenosti ukazují, že učitelé a učitelské sbory bývají vystaveni tlaku shora. Je to tendence vyřešit problémy se zaváděním změn co nejdříve a rychle prokázat nadřízeným orgánům dobré výsledky (Trubowitz, 2001). Systém práce školy, který klade důraz na akontabilitu, učitelé považují za destruktivní. Učitelé musí připravovat didaktické testy, výuka se orientuje na to, aby žáci školy byli úspěšní především v testech; učitelé jsou pod neustálým dohledem (McKenzie \& Scheurich, 2008). Mnohé změny ve školách nelze zavést izolovaně, bez účinné spolupráce školy, školských orgánů, regionálních institucí a komunity, v níž se škola nachází. Taková spolupráce vyžaduje čas a dobrou vưli, nedá se ani nadiktovat, ani uspěchat (Trubowitz, 2001). Učitelé jako aktéři změny vidí, že reálná praxe na školách se zásadně odlišuje od toho, co si o ní myslí tvưrci školské politiky. Učitelé se domnívají, že tvůrci 
reforem nejsou schopni porozumět logice uvažování praktiků, nechápou potřeby či požadavky škol, učitelů a žáků (Hartong, 2012). Rýdl (2003) dává $\mathrm{k}$ úvaze postup, jehož podstata je jednoduchá: místo centralizovaného zavádění reforem celého školského systému najednou, by bylo možné vyzkoušet decentralizované a postupné inovace. Ty by mohly být ověrovány bez rizika zpochybňování reformy jako celku. Pokud by se osvědčily a jejich př́nos by byl průkazný, pak by se postupně rozšiřovaly na celý stát (Rýdl, 2003, s. 35).

Faktory související se širším sociálně-politickým kontextem změny. $\mathrm{V}$ rámci vzdělávací politiky někdy není shoda $\mathrm{v}$ tom, co označit za klíčové vzdělávací problémy současného školství a jak by se měly řešit. V českých podmínkách šel Štech (2014) ještě dál a klade znepokojivé otázky typu: Kdo má vlastně definovat změny ve společnosti, na které se má škola adaptovat? Jak se mají tyto změny definovat?

Pokud už se decizní orgány shodnou na určité změně ve školství, je třeba připomenout, že různé typy škol a různé stupně škol dohromady tvoří vzdělávací systém, který je složitý. Přímo v něm (ale i v jeho okolí) funguje mnoho zájmových skupin. Odlišné zájmové skupiny nemusí o svůj vliv na změny školského systému jen vyjednávat. Mohou se snažit, aby jejich názor převážil, anebo usilují alespoň o paralyzování vlivu jiných zájmových skupin (Baum, 2002; Terhart, 2013). Např́íklad Van Veen a Sleegers (2005, s. 90) lakonicky konstatují, že učitelé často nebývají přizváni ke školsko-politickému rozhodování, které pak vyústí v určité inovace.
Jinak řečeno: o názor běžných učitelů není $\mathrm{v}$ takové mocenské hře zájem, což vzbuzuje u části učitelů pocit bezmocnosti, u ostatních pak odpor.

$\mathrm{V}$ tomto oddíle jsme čtenárumm přiblížili faktory, které podporují změnu a faktory bránící změně. Jak ale poznáme, kteří učitelé se vyznačují odporem ke změně? Pokud pocitují odpor ke změně, jak je intenzivní? Které složky v něm převažují? $\mathrm{Na}$ tyto otázky se snaží odpovědět další oddíl naší studie.

\section{ZJIŠŤOVÁNÍ ODPORU UČITELU゚ VƯČI ZMĚNĚ}

V zásadě můžeme př́stupy ke zjištování odporu pracovníků vưči změnám rozdělit do tří skupin: kvantitativní, kvalitativní a smíšené (kombinují oba předchozí).

\section{Kvantitativní přístup}

Výklad začneme kvantitativním přístupem. Tabulka 1 podává přehled dotazníků. Nejen těch dotazníků, které se používají u učitelů, ale i dotazníků, které se používají v jiných oborech a mohly by se rovněž používat ve školství.

Kromě výše uvedených profesionálně zkonstruovaných dotazníků se v praxi setkáváme i s dotazníky, které vytvořili sami učitelé pro potřeby jednorázového šetření. Takové dotazníky však nemají ověreny psychometrické charakteristiky, tj. neznáme jejich faktorovu strukturu, ani jejich validitu, ani vnitřní konzistentnost. Viz např. dotazník pro pedagogické pracovníky (Matějovská, 2009). 
Mareš, J.

\begin{tabular}{|c|c|c|c|c|}
\hline & 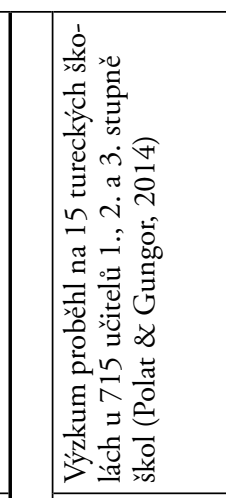 & 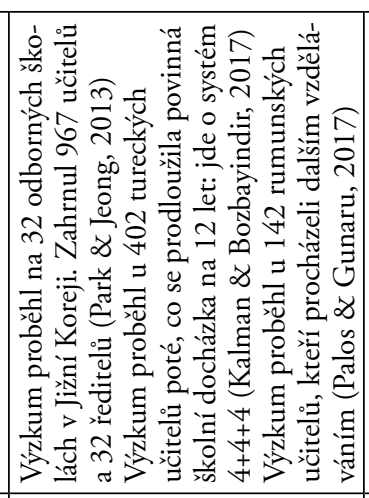 & 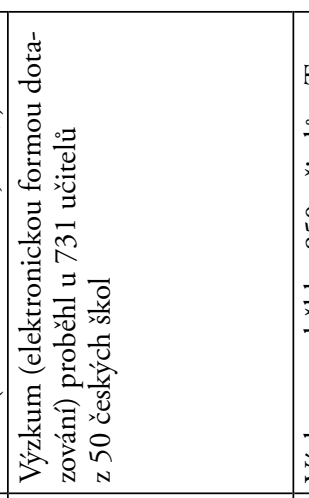 & 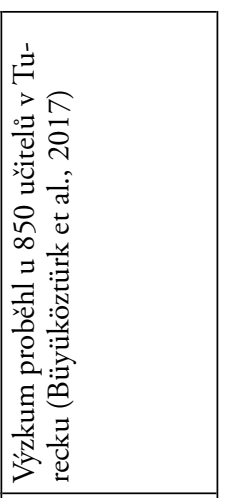 \\
\hline 造 & 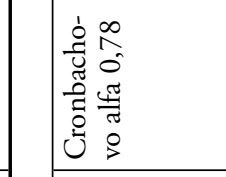 & 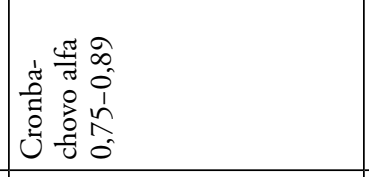 & 1 & 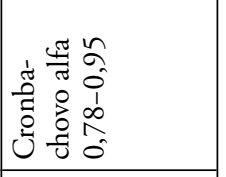 \\
\hline & 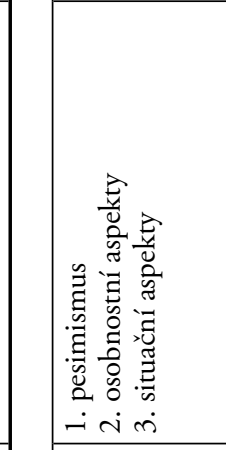 & 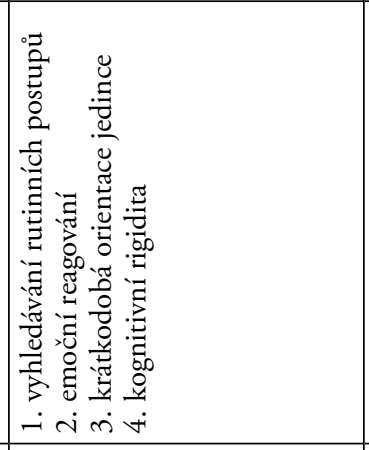 & 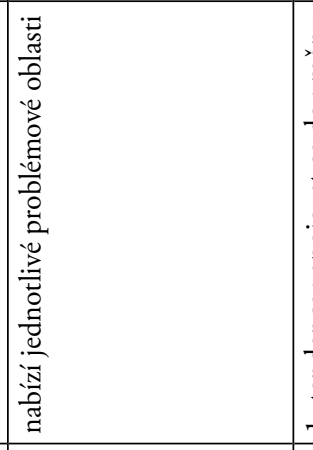 & 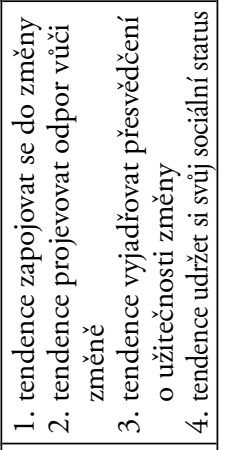 \\
\hline 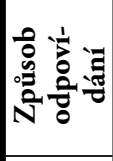 & 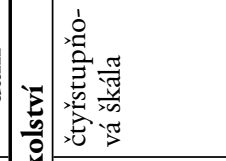 & 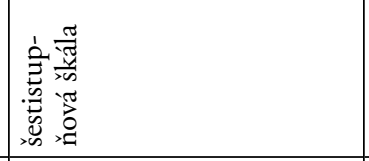 & 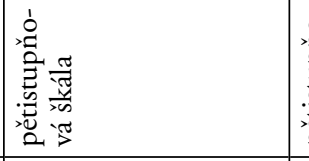 & 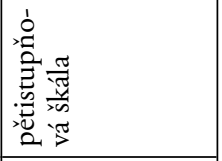 \\
\hline 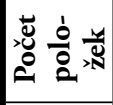 & $\mid$ & $\approx$ & $\tilde{\gamma}$ & $\vec{F}$ \\
\hline & 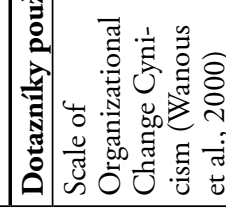 & 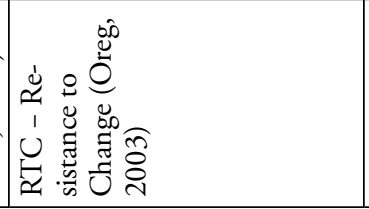 & 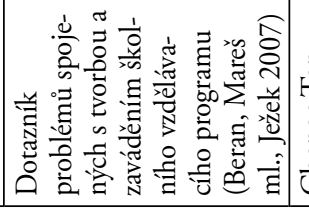 & 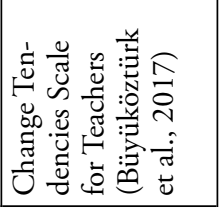 \\
\hline
\end{tabular}

\section{8}




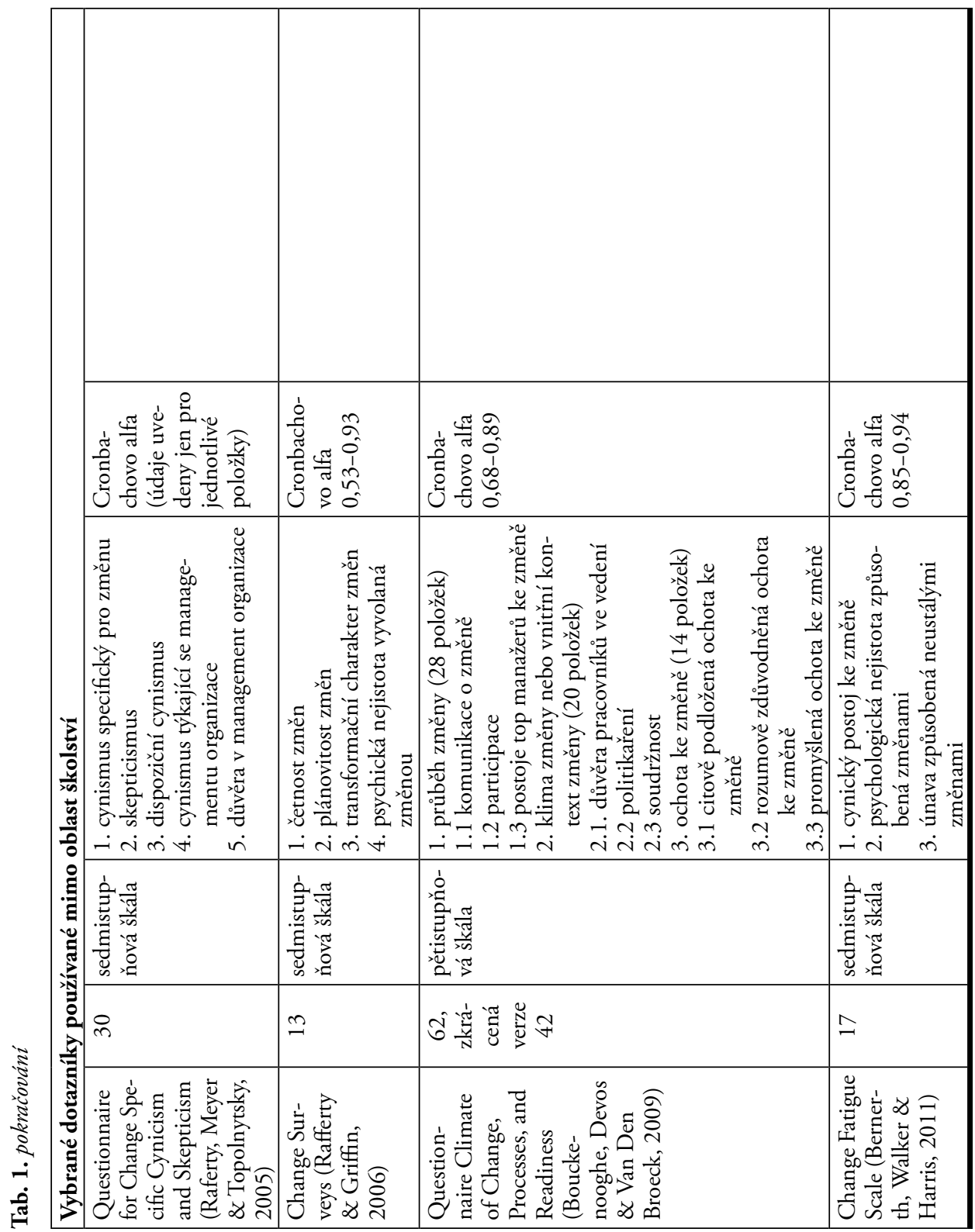


Dříve, než se čeští autoři odhodlají vytvářet vlastní kvalitní dotazníky, měli by začít $s$ překládáním zahraničních dotazníků a jejich adaptováním na české podmínky. Získají tím cenné zkušenosti. Inspirujícím může být pro ně článek, který popisuje, jak byla zajištována ekvivalentnost a validita měření pomocí dotazníku RTC (měří odpor vůči změně jako osobnostní rys). Výzkum proběhl v 17 zemích na čtyřech kontinentech, při 13 různých jazycích a v poněkud odlišných sociokulturních podmínkách (viz Oreg, Bayazit, Vacola et al., 2008).

\section{Kvalitativní přístup}

Nyní přejdeme k ukázkám kvalitativních přístupů, které se v zahraničí začínají používat stále častěji. Zde jsou některé prríklady.

Individuální rozhovory. Američanka Van Bodegravenová (2015) si položila dvě základní výzkumné otázky: 1. Jak zkušení učitelé popisují své zkušenosti s různými školskými reformami a doporučovanými postupy ve výuce, které během své učitelské praxe zažili? 2. Které vněǰší a vnitřní faktory (podle jejich zkušeností) měly bud' pozitivní, nebo negativní vliv na to, aby změnu vůbec přijali? Vybrala si osm vyučujících (dva muže a šest žen) s průměrnou délkou praxe 21 let. Vedla s nimi individuální polostrukturované rozhovory; průběh rozhovorů nahrávala a přepsala do protokolu. Texty protokolů podrobila fenomenologické analýze, přičemž využívala jednak poznatků o emoční inteligenci (sebeuvědomění, sebeovládání, sociální uvědomění, obratnost $\mathrm{v}$ mezilidském styku), jednak systémové teorie (osobní mistrovství, mentální modely, sdílení vize, týmové učení, systémové uvažování).

Individuální rozhovory a ohniskové skupiny. Američané Thornburg a Mungaiová (2011) zkoumali názory učitelů na školskou reformu, a to $\mathrm{v}$ počáteční fázi reformy. Vybrali si učitele prvního, druhého a třetího stupně ze sedmi různých škol (celkem 42 učitelů s průměrnou délkou praxe osm let). Vedli s nimi jednak individuální polostrukturované rozhovory, jednak $\mathrm{s}$ nimi organizovali diskuse $\mathrm{v}$ ohniskových skupinách. Průběh rozhovorů i diskusí nahrávali a přepsali do protokolů. Texty protokolů podrobili také fenomenologické analýze.

Př́ípadové studie. Izraelský badatel Berkovich (2011) zvolil tématem svého výzkumu unikátní situaci. V roce 2007 izraelští učitelé celkem 64 dní stávkovali proti školské reformě a pro svůj nesouhlas hledali podporu u široké veřejnosti. Autor se primárně zajímal o názory virtuálnich komunit učitelů, a proto analyzoval blogy učitelů, internetová prohlášení škol a diskuse učitelů na sociálních sítích. Zkoumaný vzorek tvořil: jeden kolektivní učitelský blog, tři osobní blogy tří učitelů a šest blogů učitelských sborů šesti škol $\mathrm{v}$ různých izraelských městech. Ve vymezeném časovém období dvou měsícủ si autor stáhl a pročetl všechny př́spěvky, které se na webových stránkách objevily. Vybral $\mathrm{z}$ nich ty, které se vztahovaly prímo $\mathrm{k}$ odmítané školské reformě. Bylo to celkem 289 př́spěvků publikovaných na blogu a 12 prohlášení učitelů a škol. Podrobil je tematické analýze. 
Americká př́padová studie (Samel, Sondergled, Ficher et al., 2011) ukazuje, že se př́ípadová studie nemusí věnovat jen jednorázové události; může jít o longitudinální zkoumání. Autoři studovali průběh a dopady federální vzdělávací reformy GEAR UP (Gaining Early Awareness and Readiness for Undergraduate Programs) $\mathrm{v}$ jednom větším městě na veřejných školách. Jednalo se o šestileté sledování kohorty 346 žáků počínaje 7 . postupným ročníkem a konče 12 . ročníkem. Zkoumali mj. klíčové události, proměny odporu $\mathrm{k}$ reformě i různé vzdělávací dráhy těchto žáků.

Česká vícepř́ípadová studie (Dvořák, Starý, Urbánek et al., 2010) měla širší záběr než jen odpor učitelů ke změnám, nebot’ výzkumná otázka zněla: Jak struktury a mechanismy na úrovni české základní školy ovlivňují vzdělávání žáků? Přesto se však řada zjištění týkala našeho tématu. Badatelé si vybrali pět českých základních škol v různých lokalitách, které se lišily svou velikostí (jednu malou, dvě střední a dvě velké). Zajímali se o činnost tří aktérů školního života: vedení škol a tedy o způsoby ŕízení škol, učitele a procesy vyučování, o žáky a procesy učení. $V$ rámci vícepř́ípadové studie používali tyto výzkumné metody: pozorování, individuální hloubkové rozhovory s pedagogickými pracovníky školy, skupinové rozhovory v rámci ohniskových skupin žáků, dotazníky pro učitele a rodiče. Badatelé také pracovali s dokumentací školy, tj. se školními vzdělávacími programy, výročními zprávami škol, inspekčními zprávami, školními časopisy, zápisy žáků, žákovskými výkresy atd. Základní principy výzkumné práce se získanými daty byly tři: triangulace dat, řetězové dokladování a validizace badatelských interpretací dat ze strany účastníků výzkumu.

\section{Smíšený přístup}

Jak jsme už výše naznačili, kombinuje kvalitativní a kvantitativní př́stup. Autoři se snaží, aby tím posilovali výhody každého z nich a kompenzovali jejich nevýhody.

V mezinárodním programu PISA, který srovnává výkony žáků různých zemí, nedopadlo v určitém období dobře Německo. Za pravděpodobnou príčinu byl označen dosavadní systém vzdělávání, který nebyl nakloněn reformám, a proto zesílily tlaky na jeho změnu. Hartong (2012) začal studovat zkušenosti škol se školskou reformou, které se odehrála v Dolním Sasku. Agentem změny se zde stala Bertelsmannova nadace, které sice vznikla v Německu, ale dnes působí v 63 zemích. Ve spolupráci s vládou této spolkové země prosazovala transformaci školství i přes nesouhlas části učitelů a přes odpor tradičních držitelů moci - učitelských svazů. Nadace podpořila školskou reformu a iniciovala sebehodnocení škol pomocí nástrojů zaměřených na autoevaluaci škol. Pokud školy chtěly tyto nástroje používat, musely se zapojit do sítě škol realizujících změnu. Dostaly dotazníkový komplet, tj. specifické dotazníky pro vedení školy, učitele, žáky a rodiče. Další metodou, kterou aktéŕi prosazující změnu použili, byly polostrukturované rozhovory s řadovými učiteli a s řediteli škol. 
Tento oddíl ukázal, jakými postupy se dá míra odporu učitelů ke změnám diagnostikovat. Z praktického pohledu je to jistě užitečné, nebot' na zjištěné výsledky mohou navázat cílené intervence. Doporučení vhodných postupů při zavádění změny, jakož i doporučení postupů, jimiž lze předcházet odporu pracovníků vůči změně, anebo snižování odporu, když už se vyskytne, jsme v naší studii ponechali stranou. Jednak jsou dobře rozpracovány v rámci managementu, jednak by tím rozsah textu neúměrně vzrostl.

\section{DISKUSE A ZÁVĚRY}

Přehledová studie se věnovala sice běžnému, ale v našich podmínkách málo prozkoumanému jevu - odporu části učitelů vưči změnám ve školách a ve školství jako celku. Studie je postavena na čtyřech základních tezích:

1. Nesouhlas až odpor části pracovníků nějaké instituce $\mathrm{k}$ navrhovaným či už zaváděným změnám je běžnou součástí profesního života a setkáváme se $s$ ním $\mathrm{v}$ mnoha oborech lidské činnosti.

2. Není snadné definovat klíčový pojem „odpor vưči změně“, protože má mnoho dimenzí a jeho praktické aplikace se objevují v mnoha vědních oborech.

3. Tato přehledová studie se soustředila na resort školství a v jeho rámci na psychologické aspekty odporu učitelů vůči změnám.

4 . Výběr prací, z nichž přehledová studie čerpá, staví na výzkumech, které pro- běhly v zemích s obdobnými sociokulturními podmínkami. ${ }^{4}$

První dvě teze vedou $\mathrm{k}$ důležité otázce. Odpor pracovníků ke změnám $\mathrm{v}$ resortu školství má jistě některé společné rysy s odporem pracovníků v jiných resortech, a proto se můžeme inspirovat př́stupy, které se použivají v jiných oborech, jiných resortech. Ale má také svá specifika. Která specifika to jsou? V odborné literatuře jsme explicitní odpověd' nenašli. Pokusili jsme se otázku zodpovědět výčtem určitých zvláštností fungování školy. Na třech místech výčet doplňujeme důležitými postřehy z české víceprrípadové studie (Dvořák, Starý, Urbánek et al., 2010). Zde jsou hlavní rozdíly:

- ve školství nejde o práci s neživými komoditami, ale o práci s lidmi;

- nejde o práci s dospělými osobami, ale převážně s dětmi a dospívajícími;

- nejde o vybrané dospělé osoby, ale o téměr celou populaci dětí a dospívajících;

- práce učitele se žáky a studenty př́mo ve vyučovacích hodinách není obvykle týmovou, ale převážně individuální záležitostí;

- učitelé jsou sice součástí instituce, tj. školy, ale pro svou práci potřebují určitou míru autonomie v rozhodování, jak koncipovat svoji práci a jak ji realizovat;

- činnost učitele není úplně rutinní, jednoduše nacvičitelná, ale zahrnuje i zvládání obtížně predikovatelných situací, jejichž řešení má závažné dopady;

- současně však platí, že se na práci s jednou trrídou postupně podílí několik vy-

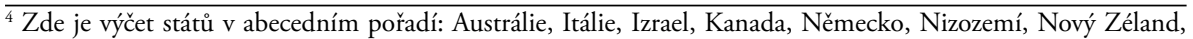
Turecko, USA, Velká Británie.
} 
učujících, což komplikuje určení podílu zúčastněných učitelů na konečném edukačním výsledku, a tím i míru odpovědnosti;

- Dvořák et al. (2010) připojuje: $\mathrm{v}$ rámci učitelského sboru nespojují jednotlivé učitele jen běžné pracovní a osobní vztahy, ale jsou propojeni prostřednictvím živé bytosti - žáka, tj. společným výchovným pưsobením na žáka a také (společně) projektovaným učivem;

- navíc - na rozdíl od mnohých jiných institucí - jsou si učitelé ve škole rovni; fungující učitelský sbor se vyznačuje soudržností, vstřícností, kolegiálností, vzájemnou pomocí (Dvořák et al., 2010, s. 189);

- kromě učitelů a vedoucích pracovníků školy se na edukačním výsledku podílí (na rozdíl od jiných resortů) do jisté míry i rodina, tj. domácí př́prava žáků a míra spolupráce rodiny se školou;

- výstupem změny v činnosti učitele není (jako $\mathrm{v}$ jiných resortech) zlepšený pracovní výkon, větší produktivita práce, kvalitnější výrobky, lepší vztahy v dané organizaci; ve školství jsou primárním výstupem žádoucí změny $\mathrm{v}$ osobnosti dětí a dospívajících - nejen rozšíření jejich znalostí, dovedností a schopnost je správně používat $\mathrm{v}$ reálných situacích, ale také příznivé změny hodnotového systému, postojů a jednání v sociálních situacích;

- u edukačních jevů se obtížně zjištuje efekt zaváděné změny: vstupní a výstupní hodnoty na straně žáků, rozsah změny nejen ve smyslu statisticky významných rozdílů, ale především ve smyslu věcně významných rozdílů, trvalosti změny, př́nosu změny nejen z pohledu průměrných hodnot za trí́dy, postupné ročníky a školy, ale také z pohledu různých typů žáků;

- Dvořák et al. (2010, s. 188) upozorňují: resort školství se oproti jiným resortům vyznačuje menší dynamičností - škola se tolik neproměňuje;

- školství funguje v hierarchicky uspořádaném prostředí, a proto bude třeba zkoumat nejen úroveň třídy, školy, ale i vyšší úrovně zavádění změn, tj. průběh zavádění změny a výsledky změny na úrovni obcí, krajů a celého státu; tím lépe poznáme i širší projevy odporu vůči změnám a můžeme cíleně reagovat.

$\mathrm{Z}$ uvedených specifik školství plyne, že přebírat zkušenosti, metody i závěry $\mathrm{z}$ výzkumů, které jsou prováděny $\mathrm{v}$ jiných resortech, lze jen $\mathrm{v}$ omezené míre a s velkou obezřetností.

Třetí teze (položit důraz na psychologické aspekty odporu vůči změně) a čtvrtá teze (inspirovat se výzkumy v zemích s obdobnými sociokulturními podmínkami) byly motivovány zjednodušením složité problematiky. Námi zvolený psychologický přístup má však dvě výrazné slabiny.

První slabina spočívá v tom, že akcent na psychologický prrístup je použitelný $\mathrm{v}$ př́padě individuálních zvláštností odporu učitelů vůči změnám ve školství. Odpor vůči změnám může mít - jak ukazují výzkumy - svůj základ v dispozičním rysu učitelovy osobnosti, může mít podobu kognitivní rigidity, vysoké úrovně vnímané vlastní zdatnosti, která nepotřebuje změny. Základem odporu mohou být také učite- 
lovy obavy a strach z neznámého, z rizik, která změna přináší, ze ztráty autonomie, z nezvládání nových požadavků, ze změny mezilidských vztahů ve sboru, ze změny pracovního zařazení, ze zhoršení své ekonomické situace. Odpor učitele se může opírat také o jeho nesouhlas s předpoklady a hodnotami, na nichž je změna postavena, či o předjímání některých dlouhodobých negativních dopadů změny, jež její zastánci neberou v úvahu.

Méně už je psychologický přístup použitelný $\mathrm{v}$ př́ípadě sociálnè-psychologických a sociologických zvláštností učitelů, tj. v případě skupin učitelů, učitelských sborů a větších skupin učitelstva. U některých skupin učitelů se objevuje nepřipravenost ke změně, neochota prrijmout změnu za vlastní, akceptovat ji a podílet se na jejím zavádění. Podle Lunenburga (2010) existují skupiny učitelů, které si vytvořily svébytné normy chování určující hranice, kam až členové skupiny mohou zajít. Pokud jedinec tyto nepsané normy nedodrží, nechová se tak, jak skupina očekává, je obvykle vystaven sociálnímu tlaku skupiny a prríp. sankcím. Pokud je taková skupinka učitelů nebo dokonce většina učitelského sboru proti změnám, jen těžko se jedinec odváží mít odlišný názor a změnu podporovat.

Sociální tlaky jsou velmi silným nástrojem. Proto vedení školy podle Dvořáka a spolupracovníků často váží, kdy zvolit sebevědomé prosazování autonomie školy a kdy se takový odpor stává pro školu kontraproduktivním. Míra tohoto zvažování se může pohybovat od úplné autonomie až po přímou závislost na ústředních tlacích na školu a na decizních požadavcích zřizo- vatelů. Jsou však školy, které ústředně koncipovaný program změny chápou jenom jako nabídku, jako možnost, která jim však nevyhovuje. Domnívají se, že zlepšení kvality pedagogické práce své školy dokáží zajistit i bez vnějších intervencí a neustálých změn. Jde tedy o citlivé vyvažování možných a nutných řešení. (Dvořák et al., 2010, s. 139-141).

Pokud jde o vztah individuálního a sociálního, př́ipojujeme se k názoru Dvořáka a spolupracovníků: „Různorodé individuální kvality každého učitele se v prostředí školy bezprostředně realizují v kontextu učitelského sboru jako celku. Učitelé z jedné strany sbor spoluvytvářejí a ovlivňují, a jako jednotlivci jsou zpětně v prostředí sboru a působení pospolitosti kolegů různou mírou regulováni.“ (tamtéž, s. 181)

Druhá slabina našeho př́stupu je závažnější a dala by se shrnout do pojmu rozdilný kontext odporu vůči změně $\mathrm{v}$ mezinárodním měřítku. Mezi různými státy existují rozdíly v podobě a fungování školských systémů, rozdíly ve vstupování dětí do různých typů škol, rozdíly $\mathrm{v}$ prrípravě budoucích učitelů, rozdíly ve způsobech výuky na školách, rozdíly v četnosti reforem i dílčích změn ve školství různých zemí, $\mathrm{v}$ prrípravě a způsobech zavádění takových změn. A to i v zemích s obdobnými sociokulturními podmínkami. Proto mohou učitelé $\mathrm{v}$ těchto zemích reagovat na změny trochu jinak než učitelé v České republice, proto i zde musíme výsledky zahraničních výzkumů brát $\mathrm{s}$ určitou rezervou.

$\mathrm{Na}$ závěr naší studie zařazujeme úvahu, kterou napsal J. D. Fife v předmluvě k práci věnované poslání vysokých škol. Pokud 
se odvážíme tuto úvahu zobecnit na poslání škol vůbec, můžeme říci toto: Je ironií osudu, že škola jako sociální systém kvůli svému poslání musí reagovat na tlaky, aby se sama změnila, ale současně musí odolávat snahám ji změnit. Škola totiž plní roli kurátora, kritika a tvůrce naší kultury. Jako kurátor musí škola chránit, udržovat a předávat dál naši kulturu. Jako kritik by měla identifikovat to, co je třeba $v$ naší kultuře změnit. Jako tvůrce by měla hrát aktivní roli při zavádění potřebných změn. Školu můžeme charakterizovat jako zrcadlo naší společnosti. Jako taková musí odrážet její změny, přizpůsobovat se změnám společnosti jako celku (modifikovaně podle Fife, 1982, s. 6). Současně - ale to už dodáváme my - nemůže být ve vleku událostí, nedomyšlených nápadů a rozhodnutí; musí si zachovávat kritický a profesionální pohled.

\section{Literatura}

Alharbi, T. S., Ekman, L., Olsson, L. E., et al. (2012). Organizational culture and the implementation of person centered care: Results from a change process in Swedish hospital care. Health Policy, 108(2/3), 294-301.

Audit vzdělávacího systému v ČR: rizika a př́ležitosti (2017). Dostupné z http://www. eduin.cz.

Baum, H. S. (2002). Why school systems resist reform: A psychoanalytic perspective. Human Relations, 55(2), 173-198.

Bauer, M. (1993). Resistance to change: A functional analysis of response to technical change in Swiss Bank. London: University of London.

Beran, J., Mareš, J. ml., \& Ježek, S. (2007). Rezervované postoje učitelů k dalšímu vzděláváni jako jeden z rizikových faktorů kurikulární reformy. Orbis scholae, 2(1), 111-130.

Berkovich, I. (2011). No we won't! Teachers' resistance to educational reform. Journal of Educational Administration, 49(5), 563-578.

Bernerth, J., Walker, H., \& Harris, S. (2011). Change fatigue: Development and initial validation of a new measure. Work Stress, 25(4), 321-337.

Bolognese, A. F. (2002). Employee resistance to organizational change. Dostupné z www.newfoundations.com

Bouckenooghe, D., Devos, G., \& Van Den Broeck, H. (2009). Organizational change questionnaire - climate of change, processes, and readiness: Development of a new instrument. Journal of Psychology, 143(6), 559-599.

Bowers, B. (2011). Managing change by empowering staff. Nursing Times, 107(32/33), 19-21.

Brand, C. F., \& Johnson, K. P. (2001). Forces for change: School in the new century. Contemporary Education, 72(1), 32-39.

Büyüköztürk, S., Uslu, Ö., \& Altun, S. A, (2017). Adaptation of Change Tendencies Scale for teachers. Kastamonu Education Journal, 25(3), 1071-1082.

Clark, C. S. (2013). Resistance to change in the nursing profession: creative transdisciplinary solutions. Creative Nursing, 19(2), 70-76. 
Coch, L., \& French, J. R. Jr. (1948). Overcoming resistance to change. Human Relations, $1(4), 512-532$.

Deneen, C., \& Boud, D. (2014). Patterns of resistance in managing assessment change. Assessment \& Evaluation in Higher Education, 39(5), 577-591.

Di Fabio, A., \& Gori, A. (2016). Developing a new instrument for assessing acceptance of change. Frontiers in Psychology, 7(802), 1-10.

Dvořák, D., Starý, K., Urbánek, P., et al. (2010). Česká základni škola. Víceprípadová studie. Praha: Karolinum.

Fife, J. D. (1982). Foreword. In R. C. Nordvall, The process of change in higher education institutions. Washington: American Association for Higher Education, Research Report No. 7, 1-58. Dostupné z https://files.eric.ed.gov

Ford, J. D., \& Ford, L. W. (2010). Stop blaming resistance to change and start using it. Organizational Dynamics, 39(1), 24-36.

Furmaníková, L., Havrdová, Z., Tollarová, B., et al. (2013). K fenoménu vůdcovství: Kým a jak je iniciován a veden proces transformace pobytových sociálních služeb? Sociální práce, 13(1), 49-60.

Garcia-Huidobro, J. C., Nannemann, A., Bacon, C. K., et al. (2017). Evolution in educational change: A literature review of the historical core of the Journal of Educational Change. Journal of Educational Change, 18, 263-293.

Gitlin, A., Margonis, F. (1995). The political aspect of reform: Teacher resistance as good sense. American Journal of Education, 103, 377-405.

Gonsiewski, M.A. (2014). Resistance to change: teacher variables that may influence acceptance of curriculum-based measurement (Doctoral dissertation). Boone: Appalachian State University.

Hambrick, D. C., \& Cannella, A. A. (1989). Strategy implementation as substance and selling. Academy of Management Executive, 3(4), 278-285.

Hargeaves, A. (1998). The emotional practice of teaching. Teaching and Teacher Education, $14(8), 835-854$.

Hartl, P., \& Hartlová, H. (2010). Velký psychologický slovník. Praha: Portál.

Hartong, S. (2012). Overcoming resistance to change: PISA, school reform in Germany and the example of Lower Saxony. Journal of Education Policy, 27(6), 747-760.

Herdman, T. H. (2013). NANDA International - Ošetřovatelské diagnózy. Definice a klasifikace. Praha: Grada.

Holt, D. T., Armenakis, A. A., Harris, S. G., et al. (2007). Toward a comprehensive definition of readiness for change: A review of research and instrumentation. In W. A. Pasmore \& R. W. Woodman (Eds.), Research in organizational change and development (s. 289-336). Bingley, UK: Emerald Group.

Hůle, D., Kaiserová, I., Kabelová, K., et al. (2015). Zavedení povinného posledního roku předškolniho vzděláváni prèed zahájením školni docházky (studie proveditelnosti). Plzeň: Společ- 
nost Tady a ted', o.p.s. Demografické informační centrum, o.s. Dostupné z www.kudyvedecesta.cz.

Hynds, A. (2010). Unpacking resistance to change within-school reform programmes with a social justice orientation. International Journal of Leadership in Education, 13(4), 377-392.

Chaining Minds. (2018). Resistance to change, 2018. [on-line] Dostupné z http://changingminds.org.

James, C., \& Jones, N. (2008). A case study of the mis-management of educational change: an interpretation from an affective standpoint. Journal of Educational Change, 9(1), 1-16.

Kalman, M., \& Bozbayindir, F. (2017). An investigation of dispositional resistance, changespecific resistance and change-related information: The case of the " $4+4+4$ " educational reform in Turkey. Multidisciplinary Journal of Educational Research, 7(2), 125-155.

Khan, K., \& Rehman, M. (2008). Employes resistance towards organizational change (Doctoral dissertation). Ronneby: Blekinge Institute of Technology.

Klonek, F. E., Lehmann-Willenbrock, N., \& Kauffeld, S. (2014). Dynamics of resistance to change: A sequential analysis of change agents in action. Journal of Change Management. (On-line).

Knight, J. (2009). What can we do about teacher resistance? Phi Delta Kappan, 90(7), 508-513.

Kohnová, J., et al. (1995). Dalši vzdèláváni učitelů základnich a střednich škol jako prostředek transformace českého školství. Praha: Pedagogická fakulta UK.

Kopárek, J. (2007). Manuál začínajicího ředitele (Bakalářská práce). Praha: Pedagogická fakulta UK. Kopárek, J. (2012). Management změny ve škole (Diplomová práce). Praha: Pedagogická fakulta UK.

Lazarová, B. (2005a). Osobnost učitele a rezistence vůči změně. Brno: Sbornik prací Filozofické fakulty brnènské univerzity U 10, 109-122.

Lazarová, B. (2005b). Psychologické aspekty profesionálního rozvoje učitelů: rezistence vůči změně. Pedagogika, 55(2), 102-118.

Lunenburg, F. C. (2010). Forces for and resistance to organizational change. National Forum of Educational Administration and Supervision Journal, 27(4), 1-10.

Mareš, J. st. (2013). Osobní reflexe událostí při zavádění strukturovaného studia učitelství. Pedagogika, 63(4), 460-484.

Matějovská, A. (2009). Změna a jeji rízeni v podminkách školy (Bakalářská práce). Praha. Pedagogická fakulta UK.

McKenzie, K. B., \& Scheurich, J. J. (2008). Teacher resistance to improvement of schools with diverse students. International Journal of Leadership in Education, 11(2), 117-133.

Mohamed, N. (2008). "I have been doing things this way for so many years; why should I change?" Exploring teachers' resistance to professional learning. New Zealand Studies in Applied Linguistics, 14(1), 19-35. 
Mutchler, S. E. (1990). Eight barriers to changing traditional behavior. Washington: ERIC Clearing House. Dostupné z www.eric.ed.gov

Novotná, K. (2011). Řizeni zmèny pedagogického procesu v mateřské škole (Bakalářská práce). Praha. Pedagogická fakulta UK.

Oreg, S. (2003). Resistance to change: Developing an individual differences measure. Journal of Applied Psychology, 88(4), 680-693.

Oreg, S. (2006). Personality, context, and resistance to organizational change. European Journal of Work \& Organizational Psychology, 15(2), 73-101.

Oreg, S., Bayazit, M., Vacola, M., et al. (2008). Dispositional resistance to change: Measurement equivalence and the link to personal values across 17 nations. Journal of Applied Psychology, 93(4), 935-944.

Palos, R., \& Gunaru, S. A. (2017). The relationship between resistance to change and Romanian teachers' attitude towards continuing education: the moderating role of conscientiousness. Journal of Education for Teaching, 43(4), 458-473

Park, H., \& Jeong, D. W. (2013). School reforms, principal leadership, and teacher resistance: evidence from Korea. Asia Pacific Journal of Education, 33(1), 34-52.

Pelikán, J. (2012). Státní vzdělávací politika jako významný problém českého školství. Pedagogická orientace, 22(4), 581-595.

Piderit, S. K. (2000). Rethinking resistance and recognizing ambivalence: a multidimensional view of attitudes toward an organizational change. Academy of Management Review, 25(4), 783-794.

Píšová, M., Hanušová, S., Kostková, M., et al. (2013). Učitel expert: jeho charakteristiky a determinanty profesního rozvoje (na pozadi výnky cizich jazykui). Brno: Masarykova univerzita.

Plachá, L. (2008). Škola v ohrožení (Diplomová práce). Brno: Filozofická fakulta MU.

Polat, S., \& Gungor, G. (2014). Relationship between organizational change cynicism and some variables in Turkish public schools. The Anthropologist, 18(3), 1019-1027.

Průcha, J. (2002). Učitel. Současné poznatky o profesi. Praha: Portál.

Raferty, D. J., Meyer, J. P., \& Topolnytsky, L. (2005). Employee cynicism and resistance to organizational change. Journal Business and Psychology, 19(4), 429-459.

Rafferty, A. E., \& Griffin, M. A. (2006). Perceptions of organisational change: A stress and coping perspective. Journal of Applied Psychology, 91(5), 1154-1162.

Rusch, E. A., \& Perry, E. A. (1993). Resistance to change: Fact or stereotype. Atlanta: Annual Meeting of the American Educational Research Association. Dostupné $\mathrm{z}$ https://files. eric.ed.gov

Rýdl, K. (2003). Inovace školských systémů. Praha: ISV.

Samel, A. N., Sondergeld, T. A., Fischer, J. M., et al. (2011). The secondary school pipeline: Longitudinal indicators of resilience and resistance in urban schools under reform. High School Journal, 94(3), 95-118.

Slavíková, L. (2008). Řízení školy a vytváření učící se organizace. Orbis scholae, 2(3), 37-51. 
Smejkal, V., \& Rais, K. (2013). Řizení jakosti ve firmách a jiných organizacích. Praha: Grada. Snyder, R. R. (2017). Resistance to change among veteran teachers: Providing voice for more effective engagement. NCPEA International Journal of Educational Leadership Preparation, 12(1), 1-14.

Soukup, J. (2011). Proces změny a motivace ke změně chování. Postgraduálni medicina, 13, 201-204.

Straková, J., Spilková, V., Friedlaenderová, H., et al. (2014). Profesní přesvědčení učitelů základních škol a studentů fakult připravujících budoucí učitele. Pedagogika, 64(1), 34-65.

Štech, S. (2014). Potíže s interpretací změn. Pedagogika, 64(1), 1-4.

Terhart, E. (2013). Teacher resistance against school reform: reflecting an inconvenient truth. School Leadership \& Management, 33(5), 486-500.

Thomas, R., \& Hardy, C. (2011). Reframing resistance to organizational change. Scandinavian Journal of Management, 27(3), 322-331.

Thornburg, D. G., \& Mungai, H. (2011). Teacher empowerment and school reform. Journal of Ethnographic \& Qualitative Research, 5(4), 205-217.

Trpišovský, A. (2007). Management změny: problematika ř́zeni sloučených škol (Bakalářská práce). Praha. Pedagogická fakulta UK.

Trubowitz, S. (2001). Predictable problems in achieving large scale change. Phi Delta Kappan, 82(2), 166-168.

Val, M. P., \& Martínez-Fuentes, C. (2003). Resistance to change: a literature review and empirical study. Management Decision, 41(2), 148-155.

Van Bodegraven, B. (2015). Implementing change: How, why, and when teachers change their classroom practices (Doctoral dissertation). Minneapolis: Walden University.

Van Veen, K., \& Sleegers, P. (2006). How does it feel? Teachers' emotions in a context of change. Journal of Curriculum Studies, 38(1), 85-111.

Výrost, J. (1989). Sociálno-psychologický výskum postojov. Bratislava: Veda.

Waddell, D., \& Sohal, A. S. (1998). Resistance: A constructive tool for change management. Management Decision, 36(8), 543-548.

Wanberg, C. R., \&Banas, J. T. (2000). Predictors and outcomes of openness to changes in a reorganizing workplace. Journal of Applied Psychology, 85(1), 132-142.

Wanous, J. P., Reichers, A. E., \& Austin, J. T. (2000). Cynicism about organizational change measurement antecedents and correlates. Group \& Organizational Management, 25(2), $132-153$.

Yilmaz, D., \& Kiliçoğlu, G. (2013). Resistance to change and ways of reducing resistance in educational organizations. European Journal of Research on Education, 1(1), 14-21.

Zelená, L. (2011). Postoj učiteli k nové kurikulární reformě (Diplomová práce). Praha: Fakulta sociálních věd UK.

Ženka, O. (2007). Projevy odporu ke zmèně v organizaci s dưrazem na skupinovou dynamiku (Diplomová práce). Brno: Fakulta sociálních studií MU. 
prof. PhDr. Jiri Mareš,

Ústav sociálniho lékařství, Lékařská fakulta v Hradci Králové, Univerzita Karlova;

e-mail:mares@lfhk.cuni.cz

\section{MAREŠ, Jiř́i. Resistance of Teachers to Changes in Schools and School System}

This review study notes that the implementation of changes in education (from major reforms to changes at the level of a particular school) usually results in objections of part of teachers. The study stresses psychological view on resistance of teachers to changes in schools and school system. The study is structured into five parts. The first part of the study approaches the different concepts of "change" in the school context. The second part describes the difficulties associated with defining the term "resistance to change". It points out that the critical attitudes of teachers to change do not fully overlap with total negation of change. Not only teachers' attitudes and behaviour are rather ambivalent and tend to change over time but they may also have a positive function: they maintain the stability of the system; prevent superficial, ill-conceived changes and uncritically accepted innovations. If management listens to teacher' opinions, they can initiate a thorough debate and can provide stimuli to improve the original form of change. Seriously conceived resistance to change can change the change for the better. The third part gives an overview of factors that contribute to the promotion or resistance of teachers to change. The fourth part focuses on methods used to assessment the resistance to change and presents basic information about questionnaires, qualitative and mixed methods used for this purpose. The final part reflects on the probable differences between resistance of teachers to changes in schools and school system and resistance of employees in other institutions and sections. It suggests that there are differences of school system and its function even between countries with similar socio-cultural conditions.

Key words: school system, school, change, resistance to change, teachers, assessment. 